\title{
RESPONSE OF ABELMOSCHUS ESCULENTUS L. FORINOCULATION WITH MY CORRHIZAE AND FOLAIR APPLICATION WITH BIO- STIMULATORS AND EFFECT ON VEGETATIVE GROWTH CHARACTERS
}

\section{M.M. A. AL-Samarai}

Assist. prof.

\section{R.M. A. Al-Ubaidy}

Assist. prof.

\section{Horticulture Department}

\begin{abstract}
University of Baghdad
ABSTRACT

The current study was carried out at the Fields belongs of Horticulture Department, Collage of Agricultural Engineering Science, University of Baghdad, Al-Jadiriyah for the spring season 2016 -2017 to study the effect for inoculation mycorrhizae and folair application with bio stimulators and their interaction in the growth characters of (local okra ptera). A factorial experiment $(2 \times 3 \times 2)$ in randomized complete block design (RCBD), the experiment included (12) treatment Distributed in three replicates. The three factors used in this experiment included. The inoculation with control (C) Mycorrhizae ( M ), Biozyme (B ) ( B1 $\left.2 \mathrm{~cm}^{3} \cdot \mathrm{L}^{-1}\right),(\mathrm{B} 2$ $\left.4 \mathrm{~cm}^{1 \cdot} \cdot \mathrm{L}^{-1}\right)$, Phosphalas (P) $\left(\mathbf{P} 2 \mathrm{~cm}^{3} \cdot \mathrm{L}^{-1}\right),(\mathrm{M}+\mathrm{B} 1),(\mathrm{M}+\mathrm{B} 2),(\mathbf{P}+\mathrm{M}),(\mathbf{P}+\mathrm{B} 1),(\mathbf{P}+\mathrm{B} 2),(\mathrm{M}+\mathrm{P}+\mathrm{B} 1),(\mathrm{M}+$ $P+B 2)$. The data were analyzed according to the design followed and the mean was tested by the lowest significant difference at $0.05 \%$. The results showed a significant increase in the studied traits . The results showed that the three factors and their interactions had significant effects on most of the growth characters measured. The inoculation with the Mycorrhizae , Biozyme and Phosphalas was superior in giving higher values of plant height (M1B2P1) $120.00 \mathrm{~cm}$, Main branches number per plant 13.00, number of leaves 197.0 (Leaf .plant $\left.{ }^{-1}\right)$, leaf area $394.0\left(\mathrm{dcm}^{2}\right.$. Leaf ), fresh weight of vegetative $3200\left(\mathrm{~kg}^{-}\right.$plant $\left.^{-1}\right)$ Dry weight of vegetative 209.0 ( g plant $^{-1}$ ), number of nodules on the stem 41.33 (nod. plant ${ }^{-1}$ ), relative chlorophyll content (SAPD) respectively. The M1B2P0 combination treatment recorded the highest values of secondary branches number per plant 10.33. The M1B1P0 treatment recorded the highest values of diameter of stem $4.03(\mathrm{~cm})$.
\end{abstract}

Key words: okra, mycorrhizae, biozyme, phosphalas

السـامرائي و آخرون

مجلة العلوم الزراعية العراقية -71-61:2020 :51(عدد خاص)

استجابة الباميا للتلقيح بالمايكوريزا والرش بالمخدبات المبات الحيوية وتأثيرها على صفات النمو الخضرية

حسين حميد عبود العمراني

مدرس مساعد

رضا مصطفى عبد الحسين العبيدي

استاذ مساعد

محمد مصطفى علاوي السامرائي

استاذ مساعد

قسم البستنه وهندسة الحدائق /كلية الزراعة / جامعة القادسية مداعية

قسم البستنة وهندسة الحدائق / كلية الزراعة / جامعة بغداد مساع

(المستخلص

أجريت الدراسة في حقول قسم البستنة / كلية علوم الهندة الزراعية / جامعة بغداد / الجادرية / للموسم الربيعي 2016 - 2017 البادي

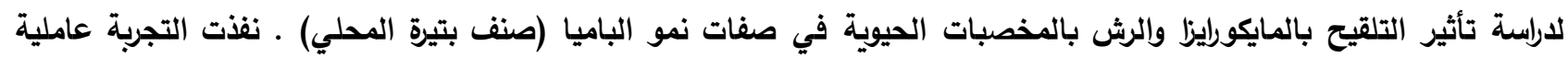

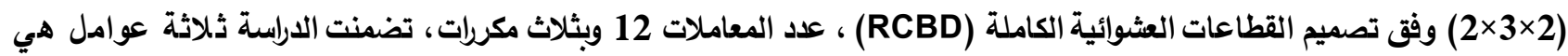

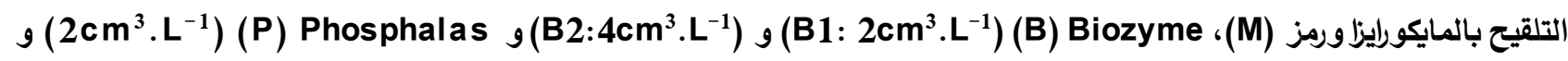

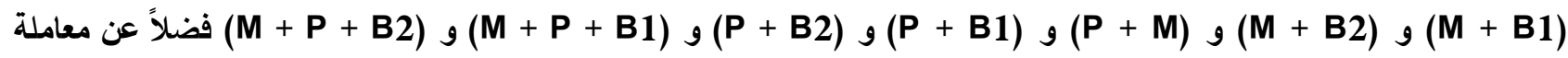
المقارنة (C). أخذت القراءات وحلت حسب التصميم المتبع وأختبرت المتوسطات حسب اختبار أقل فرق معنوي على مستوى

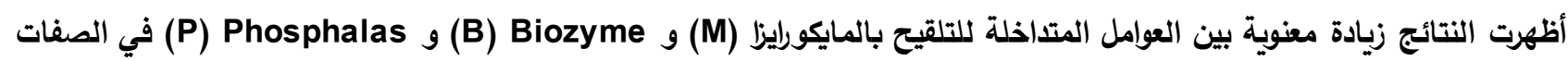
المدروسة، إذ أعطت المعاملة (M1B2P1) في ارتفاع النبات 120.00 (سم) وعدد الأفرع الرئيسية 13.00 (فرع.نبات -1 ) وعدد الأوراق

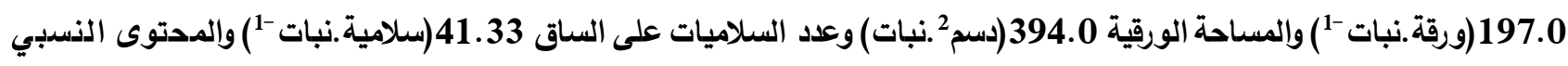

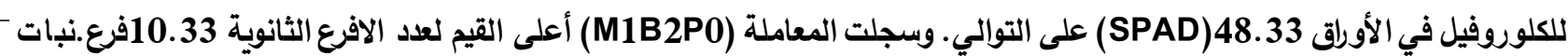

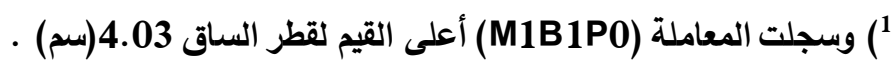
الكلمات المفتاحية: الباميا، المايكورايزا ، البايوزيم ، الفوسفوليز 


\section{INTRODUCTION}

Abelmoshus esculentus L. belongs to the Malvaceae family, one of the important summer vegetable crops in Iraq, which is characterized as one of vegetable crops whose seeds are highly desirable in Iraq. The okra is grown for the purpose of green corns that are eaten after cooking or dried, frozen, cooked and then cooked. The original habitat of okra is the region of Abyssinia, Eritrea, Central Africa, Sudan and Egypt, and from there it moved to the Mediterranean basin, India and the Arabian Peninsula. Okra plant is a good source of nutrients, carbohydrates and proteins . Each cloud of fresh coriander contains $88.9 \%$ water and 36 calories, $2.4 \%$ protein, $6.7 \%$, $0.051 \%$ phosphorus, $0.092 \%$ carbohydrate, and riboflavin and thiamine, vitamin C (20) .The microorganisms are spread in all types of soils and in a wide range of ecosystems, extending to the desert, tropical, forest, aquatic, and soils (10). It was studied decades ag. Bio-fertilizers are important factors that provide the plant with the need for nutrient elements by changing the form of unavarable to available from, which contributes to reduce the need of the plant for chemical fertilizers by $25 \%$ and reduce the costs of agricultural operations (8), (11). In a study conducted by (14). found that the use of the microorganism in the inoculation of potato tubers led to a $20 \%$ increase in plants. The use of organic compounds and extracts contributes to the improvement of plant growth due to its nutrient components such as Nitrogen,

\section{Treatments}

\section{1-The control ( C )}

2-Mycorrhizae ( M )

3-Biozyme $\left(2 \mathrm{~cm}^{3} \cdot \mathrm{L}^{-1}\right)$ ( B1)

4-Biozyme $\left(4 \mathrm{~cm}^{3} \cdot \mathrm{L}^{-1}\right)(\mathrm{B} 2)$

Study characters

\section{1- Plant height ( cm )}

2- Main branches of number per plant (branch . plant $^{-1}$ ).

3- Secondary branches of number per plant

(branch • plant ${ }^{-1}$ )

4- Number of leaves ( Leaf .plant ${ }^{-1}$ ).

5- Leaf area ( $\mathrm{dcm}^{2}$. Leaf )

6- Fresh weight of Vegetative ( $\mathrm{kg} \cdot$ plant $^{-1}$ ) plant $^{-1}$ ).

7- Dry weight of Vegetative $\left(\mathrm{g} \cdot\right.$ plant $\left.^{-1}\right)$

8-Diameter of Stem $(\mathrm{cm})$.
Phosphorus, Potassium, Iron, Copper, Boron, Zinc, etc. (22), as well as because they contain many plant hormones such as Auxin, Gibberellins and Cytokinin (21) and plant growth vegulalators organizations have a significant role in the physiological processes that relate to plant growth and harvest, plant growth regulators (7). Biozyme and Phosphalas are industrial products containing various growth regulators The aim of the experiment was to determine the extent of the response of the bamia crop to the inoculation with mycorrhizae and folair application with Biozyme and Phosphalas in the growth vegetative characteristics.

\section{MATERIALS AND METHODS}

The research was carried out in the fields of Horticulture Department , College of Agricultural Engineering University of Baghdad / Al-Jadriya Compus at Spring season $2016-2017$ to study the effect of inoculation with mycorrhizae and folair application with bio stimulators and their interaction on the growth and quantitative and qualitative yield of the (local okra). The seeds of the okra were planted in the field during the month of March on rows with distance of $30 \mathrm{~cm}$ between plants and $75 \mathrm{~cm}$ between rows, the length of the rows was $3 \mathrm{~m}$ with 10 plants included, followed the design of (RCBD). The experiment included (12) treatment distributed to three replicates [17] . The plants were sprayed after three weeks of planting and after two weeks.

$$
\begin{aligned}
& \text { 5- Phosphalas }\left(2 \mathrm{~cm}^{3} . \mathrm{L}^{-1}\right) \quad(\mathrm{P}) \quad \text { 9- P + B1 } \\
& \text { 6- } \mathrm{M}+\mathrm{B} 1 \quad \mathbf{1 0}-\mathrm{P}+\mathrm{B2} \\
& \text { 7- } \mathrm{M}+\mathrm{B} 2 \text { 11- } \mathrm{M}+\mathrm{P}+ \\
& \text { 8- } P+M \quad 12-M+P+B 2
\end{aligned}
$$

9-The number of nodules on the stem (nod . plant $\left.^{-1}\right)$.'

10- Total chlorophyll estimation ( SPAD) RESULTS AND DISCUSSION

Plant height $(\mathrm{cm})$

It was clear from table 1 that there was a significant increase in plant height due to the inoculation with the mycorrhizae. Inoculation (M1) recorded higher values for plant height $(111.94 \mathrm{~cm})$ than that for non-inoculated plants $(104.06 \mathrm{~cm})$. Also, treatment with (Biozyme) resulted in significant increase in 
plant height especially at $2 \mathrm{~cm} . \mathrm{L}^{-1}$ (B1), $109.75 \mathrm{~cm}$ compared to $105.17 \mathrm{~cm}$ for the control . Treatment with the Phosphalas (P1) recorded significant increase in plant height of $112.22 \mathrm{~cm}$ while in control treatment the plant height was $103.78 \mathrm{~cm}$. For the interaction between the inoculation with mycorrhizae and folair application with the Biozyme (M1B2) combination treatment was superior and it gave the highest value in plant height (114. $50 \mathrm{~cm}$ ), while in control treatment the plant height was $(99.33 \mathrm{~cm})$. In the same way, for interaction between the inoculation with the mycorrhizae and the spray with the
Phosphalas (M1P1) combination treatment resulted in height plants with an average plant height of $118.22 \mathrm{~cm}$ in compare to that for the control M0P0 $(101.89 \mathrm{~cm})$. Also the (B2P1) combination treatment, interaction between Biozyme and the Phosphalae, gave the highest plant height $(112.00 \mathrm{~cm})$, while the control treatment gave the lowest plant height $(98.00$ $\mathrm{cm})$. Interaction among the three factors has also significant effect. The (M1B2P1) combination treatment resulted in higher plants with an average of $120.00 \mathrm{~cm}$ ) compare to $(91.67) \mathrm{cm}$ for the control treatment (M0B0P0)

Table 1. Effect of Mycorrhizae, spray with Biozyme and Phosphalas on the plant height (cm) of okra cv. Ptera

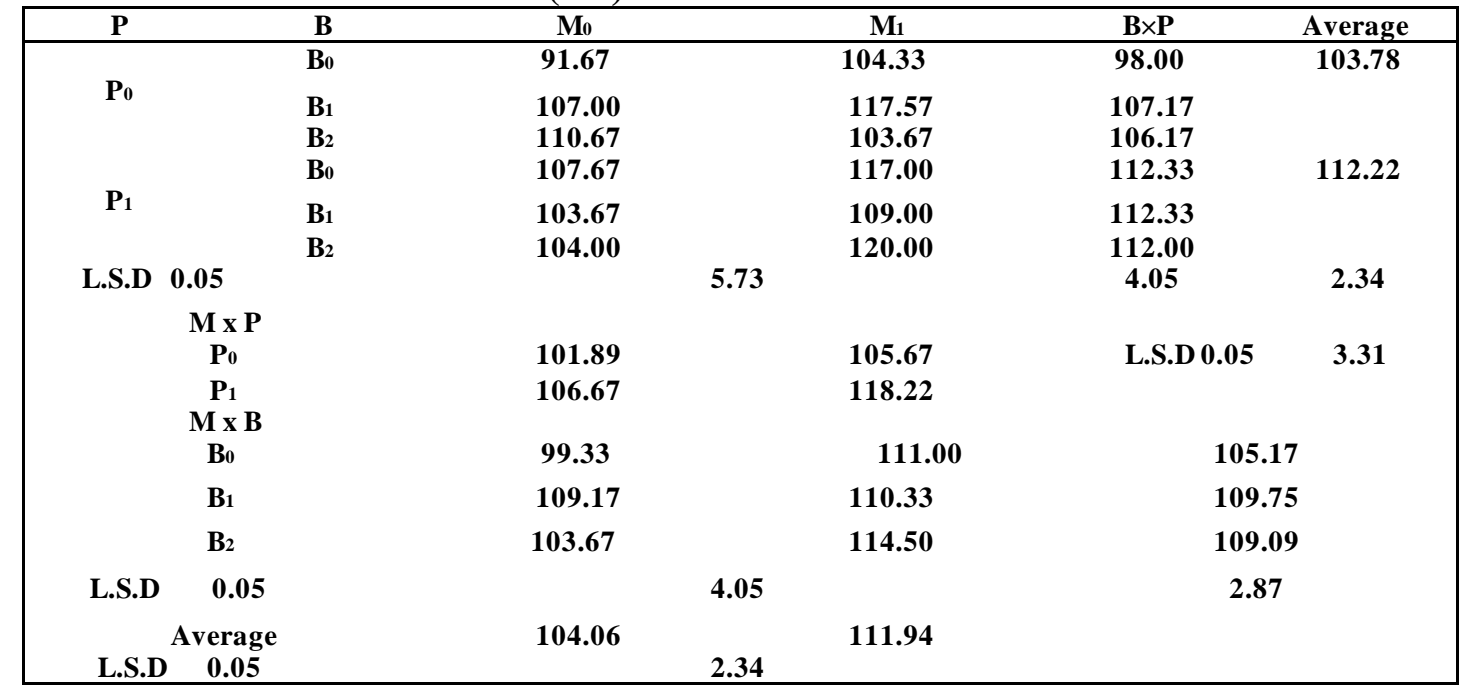

\section{2- Main branches number of per plant $^{-1}$}

Table 2 demonstrates the significant effect of the inoculation with the mycorrhizae on the main branches number per plant. The inoculation treatment (M1) resulted in higher main branches number of per plant (9.50) than that for the control (7.11). Also for the Biozyme treatments effects, $4 \mathrm{~cm} . \mathrm{L}^{-1}$ (B2) treatment recorded the highest of main branches number per plant (9.00) in compare to( 7.42) for the treatment (B1). Spraying the Phosphalas on plants have also promoting effect on main branches number per plant . Higher of main branches number of per plant was recorded at $(\mathrm{P} 1)$ treatment $(9.56)$ in compare to (7.06) for the control (P0). It was obvious from the same table that the interaction between the mycorrhizae and spray with the Biozyme significantly increased of main branches number of per plant. At the M1B2 combination treatment, the main branches number of per plant was (10.50) while main branches number per plant at the control was much lower (7. 00). With regard to the effect of the combination between the mycorrhizae and the Phosphalas significant effect was also noticed the M1P1combination treatment recorded the highest main branches number of per plant (11.11) while the control treatment recorded the lower main branches number of per plant (6.22). For the combination between Biozyme and the Phosphalas treatments increased main branches number of per plant (10.50) while the (B1P0) treatment the lower main branches number of per plant (6.67). As for other parameter measured, the number of leaves was affected by the combination among the three factors. The M1B2P1 combination treatment was superior in giving the highest main branches number of (13.00) the least main branches number of per plant was at the control treatment M0B0P0 (4.67). 
Table 2. Effect of Mycorrhizae, spray with Biozyme and Phosphalas in the main branches number of per plant ${ }^{-1}$ of okra cv. Ptera

\begin{tabular}{|c|c|c|c|c|c|c|c|c|}
\hline $\mathbf{P}$ & & B & $\mathbf{M}_{0}$ & & $\mathbf{M}_{1}$ & $\mathbf{B} \times \mathbf{P}$ & & Average \\
\hline & & $\mathbf{B}_{0}$ & 4.67 & & 9.33 & 7.00 & & 7.06 \\
\hline \multirow[t]{3}{*}{$\mathbf{P}_{0}$} & & $\mathbf{B}_{1}$ & 9.00 & & 11.00 & 6.67 & & \\
\hline & & $\mathbf{B}_{2}$ & 7.00 & & 6.33 & 7.50 & & \\
\hline & & $\mathbf{B}_{0}$ & 7.00 & & 9.33 & 10.00 & & 9.56 \\
\hline \multirow{2}{*}{$\mathbf{P}_{1}$} & & $\mathbf{B}_{1}$ & 7.00 & & 8.00 & 8.17 & & \\
\hline & & $\mathbf{B}_{2}$ & 8.00 & & 13.00 & 10.50 & & \\
\hline \multirow[t]{7}{*}{ L.S.D } & $\begin{array}{l}0.05 \\
\mathbf{M} \times \mathbf{P}\end{array}$ & & & 1.49 & & 1.05 & & 0.61 \\
\hline & $\mathbf{P}_{0}$ & & 6.22 & & 8.00 & L.S.D & 0.05 & 0.86 \\
\hline & $\mathbf{P}_{1}$ & & 7.89 & & 11.11 & & & \\
\hline & M x B & & & & & & & \\
\hline & $\mathbf{B}_{0}$ & & 7.00 & & 7.83 & & 7.42 & \\
\hline & $B_{1}$ & & 6.83 & & 10.17 & & 8.50 & \\
\hline & $\mathbf{B}_{2}$ & & $\mathbf{7 . 5 0}$ & & 10.50 & & 9.00 & \\
\hline \multirow[t]{2}{*}{ L.S.D } & 0.05 & & & 1.05 & & & 0.74 & \\
\hline & Average & & 7.11 & & 9.50 & & & \\
\hline L.S.D & 0.05 & & & 0.61 & & & & \\
\hline
\end{tabular}

\section{3- Secondary branches number per plant $^{-1}$}

Table 3 demonstrates the significant effect of the inoculation with the mycorrhizae on the main branches number per plant. The inoculation treatment (M1) resulted in higher secondary branches number of per plant (7.28) than that for the control (5.28) (M0) . Also for the Biozyme treatments effects, $2 \mathrm{~cm}$. $\mathrm{L}^{-1}$ (B1) treatment recorded the highest of secondary branches number per plant (7.17) in compare to(4.83) for the treatment (B0). Spraying the Phosphalas on plants have also promoting effect on secondary branches number per plant. Higher of secondary branches number per plant was recorded at (P0) treatment (6.39) in compare to (6.17) for the $(\mathrm{P} 1)$ treatment . It was obvious from the same table that the interaction between the mycorrhizae and spray with the Biozyme significantly increased of seconary branches number per plant. At the M1B1 combination treatment, the secondary branches number per plant was (8.33) while secondary branches number per plant at the control was much lower (3.83). With regard to the effect of the combination between the mycorrhizae and the Phosphalas significant effect was also noticed the M1P1combination treatment recorded the highest secondary branches number per plant (7.56) while the control treatment recorded the lower secondary branches number per plant (4.78). For the combination between Biozyme and the Phosphalas treatments increased secondary branches number per plant recorded the highest (8.67), while the control treatment recorded the lower secondary branches number per plant (3.67). As for other parameter measured, secondary branches number of was affected by the combination among the three factors. The M1B2P0 combination treatment was superior in giving the highest secondary branches number of (10.33) the least secondary branches number per plant was at the control treatment MOB0P0 (3.00).

Table 3. Effect of Mycorrhizae spray with Biozyme and Phosphalas in the sacandary branches number of per plant ${ }^{-1}$ of okra cv. Ptera

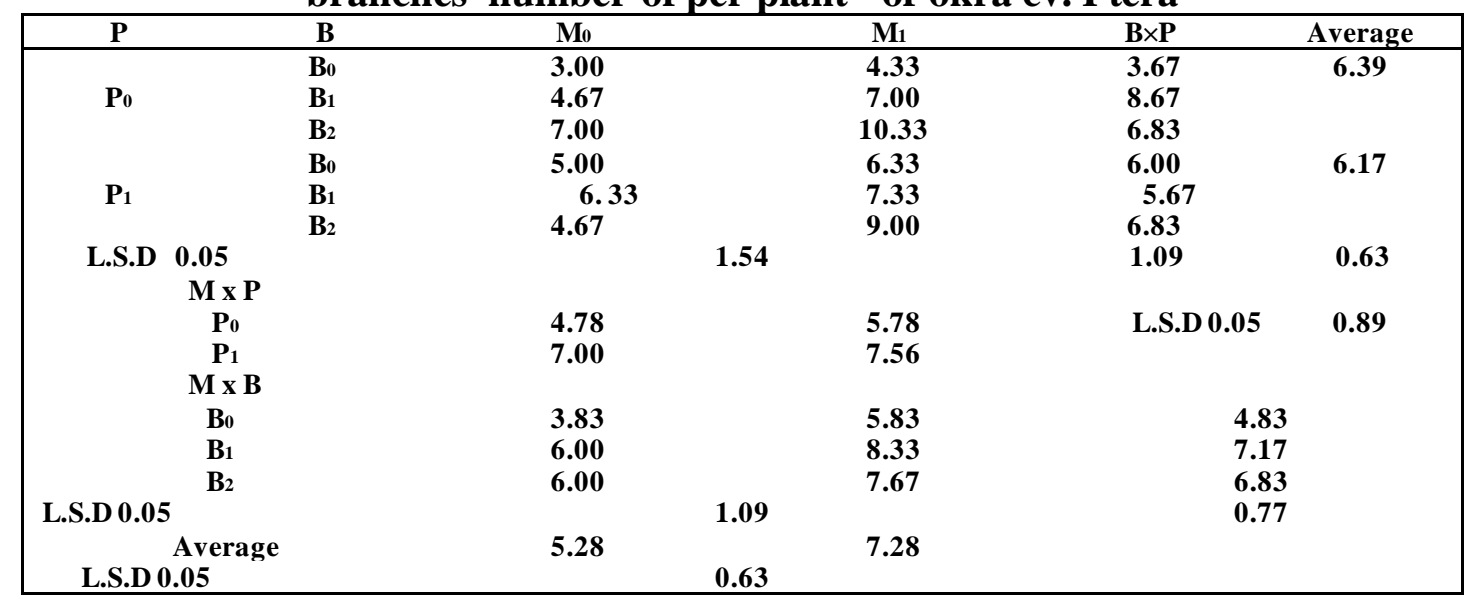




\section{4-Number of leaves (leaf. Plant ${ }^{-1}$ )}

Table 4 demonstrates the significant effect of the inoculation with the mycorrhizae on the total number of leaves. The inoculation treatment (M1) resulted in higher number of leaves per plant (180.3) than that for the control (132.2). Also, for the Biozyme treatments effects, $4 \mathrm{~cm} . \mathrm{L}^{-1}$ (B2) treatment recorded the highest number of leaves (167. 3 ) in compare to (147.5) leaves .plant ${ }^{-1}$ for the control ( B0) . Spraying the Phosphalas on plants have also promoting effect on total leaves number. Higher ${ }^{1}$ number of leaves per plant was recorded at (P1) treatment (162.7) in compare to (149. 9 leaves . plant ${ }^{-1}$ ) for the control . It was obvious from the same table that the interaction between the mycorrhizae and spray with the Biozyme significantly increased number of leaves. At the M1B1 combination treatment, the total number of leaves per plant was (189.8) while the number at the control was much lower (166 .8 leaf. Plant $^{-1}$ ) .. With regard to the effect of the combination between the mycorrhizae and the Phosphalas significant effect was also noticed the M1P1combination treatment recorded the highest number of leaves (183. 4) which did not differ from the M1P0 combination treatment, while the control treatment recorded the lower number of leaves per plant (122.6) . For the combination between Biozyme and the Phosphalas treatments increased significantly leaves number per plant (171.8) while the control treatment was are the lower number of leaves per plant (141.0) . As for other parameter measured,the number of leaves was affected by the combination among the three factors. The M1B0P0 combination treatment was superior in giving the highest number of leaves 197.0 the least number of leaves was at the control treatment M0B0P0 (84.0).

Table 4. Effect of Mycorrhizae, spray with Biozyme and Phosphalas on total number of leaves per plant (Leaves. Plant ${ }^{-1}$ ) of okra cv. Ptera

\begin{tabular}{|c|c|c|c|c|c|}
\hline $\mathbf{P}$ & B & $\mathbf{M}_{0}$ & $\mathbf{M}_{1}$ & $\mathbf{B} \times \mathbf{P}$ & Average \\
\hline & $\overline{\mathbf{B}_{0}}$ & 84.0 & 198.0 & 141.0 & 149.9 \\
\hline \multirow{3}{*}{$\mathbf{P}_{0}$} & $\mathbf{B}_{1}$ & 152.3 & 182.7 & 145.8 & \\
\hline & $\mathbf{B}_{2}$ & 129.7 & 162.0 & 162.8 & \\
\hline & $\mathbf{B}_{0}$ & 126.7 & 171.7 & 167.0 & 162.7 \\
\hline \multirow[t]{2}{*}{$\mathbf{P}_{1}$} & $\mathbf{B}_{1}$ & 154.0 & 171.7 & 149.2 & \\
\hline & $\mathbf{B}_{2}$ & 146.7 & 197.0 & 171.8 & \\
\hline \multirow[t]{6}{*}{ L.S.D } & $\begin{array}{c}0.05 \\
M \times P\end{array}$ & & 21.52 & 15.21 & 8.78 \\
\hline & $\mathbf{P}_{0}$ & 122.6 & 177.2 & L.S.D 0.05 & 12.42 \\
\hline & $\begin{array}{c}\mathbf{P}_{1} \\
\mathbf{M} \times \mathbf{B}\end{array}$ & 141.9 & 183.4 & & \\
\hline & $\mathbf{B}_{0}$ & 128.2 & 166.8 & 147.5 & \\
\hline & $\mathbf{B}_{1}$ & 118.2 & 189.8 & 154.0 & \\
\hline & $\mathbf{B}_{2}$ & 150.3 & 184.3 & 167.3 & \\
\hline \multirow{2}{*}{ L.S.D } & 0.05 & & 15.21 & 10.76 & \\
\hline & $\begin{array}{l}\text { Average } \\
0.05\end{array}$ & 132.2 & 8.78 & & \\
\hline
\end{tabular}

\section{5- Leaf area $\left(\mathrm{Dcm}^{2}\right.$.plant $\left.{ }^{-1}\right)$}

Table 5 demonstrates the significant effect of the inoculation with the mycorrhizae on the leaf area the inoculation treatment (M1) resulted in higher leaf area $\left(346.04 \mathrm{dcm}^{2}\right.$. plant $\left.^{-1}\right)$ than that for the control $\left(317.44 \mathrm{dcm}^{2}\right.$ . plant $\left.{ }^{-1}\right)$. Also for the Biozyme treatments effects $4 \mathrm{~cm} . \mathrm{L}^{-1}$ (B2) treatment recorded the highest leaf area $\left(352.13 \mathrm{dcm}^{2}\right.$. plant $\left.{ }^{-1}\right)$ in compare to $\left(314.32 \mathrm{dcm}^{2}\right.$. plant $\left.{ }^{-1}\right)$ for the control (B0) . Spraying the Phosphalas on plants have also promoting effect on leaf area. Higher of leaf area was recorded at ( P1) treatment $\left(343.53 \mathrm{dcm}^{2}\right.$. plant $\left.{ }^{-1}\right)$ in compare to $\left(314.96 \mathrm{dcm}^{2}\right.$. plant $\left.{ }^{-1}\right)$ for the control. It was obvious from the same table that the interaction between the mycorrhizae and spray with the Biozyme significantly increased leaf area. At the M1B2 combination treatment, the leaf area was $\left(370.24 \mathrm{dcm}^{2}\right.$. plant $^{-1}$ ) while the leaf area at the control was much lower $\left(297.23 \mathrm{dcm}^{2}\right.$. Plant $\left.{ }^{-1}\right)$. With regard to the effect of the combination between the mycorrhizae and the Phosphalas significant effect was also noticed the M1P1combination treatment recorded the highest number of leaf area (394. $10 \mathrm{dcm}^{2}$. Plant $^{-1}$ ), while the control treatment recorded the lower $\left(278.52 \mathrm{dcm}^{2}\right.$. Plant $\left.\mathrm{C}^{-1}\right)$. For the combination between Biozyme and the Phosphalas treatments increased significantly leaf area $\left(357.24 \mathrm{dcm}^{2}\right.$. Plant $\left.{ }^{-1}\right)$ while the 
control treatment are the lower leaf area $\left(297 . .80 \mathrm{dcm}^{2}\right.$. Plant $\left.{ }^{-1}\right)$. As for other parameter measured the leaf area was affected by the combination among the three factors.
The M1B2P1 combination treatment was superior in giving the highest leaf area (394. $10 \mathrm{dcm}^{2}$. Plant ${ }^{-1}$ ) was at the control treatment M0B0P0 (278.52 dcm $\mathrm{dc}^{2}$. Plant $\left.{ }^{-1}\right)$.

Table 5. Effect of Mycorrhizae, spray with Biozyme and Phosphalas on Leaf area ( Dem ${ }^{2}$ ) of okra cv. Ptera

\begin{tabular}{|c|c|c|c|c|c|c|c|}
\hline \multirow[t]{2}{*}{$\mathbf{P}$} & & B & $\mathbf{M}_{0}$ & & $\overline{M_{1}}$ & $\mathbf{B} \times \mathbf{P}$ & Average \\
\hline & & $\overline{\mathbf{B}_{0}}$ & 278.52 & & 317.08 & 297.80 & 319.96 \\
\hline \multirow[t]{3}{*}{$\mathbf{P}_{0}$} & & $\mathbf{B}_{1}$ & 315.95 & & 345.74 & 315.06 & \\
\hline & & $\mathbf{B}_{2}$ & 310.50 & & 319.61 & 347.01 & \\
\hline & & $\mathbf{B}_{0}$ & 331.64 & & 353.35 & 330.84 & 343.53 \\
\hline \multirow[t]{2}{*}{$\mathbf{P}_{1}$} & & $\mathbf{B}_{1}$ & 347.65 & & 346.38 & 342.50 & \\
\hline & & $\mathbf{B}_{2}$ & 320.10 & & 394.10 & 357.24 & \\
\hline \multirow[t]{6}{*}{ L.S.D } & 0.05 & & & 9.32 & & 6.59 & 3.81 \\
\hline & $\underset{\mathbf{P}_{0}}{\mathbf{M} \times \mathbf{P}}$ & & 312.22 & & 327.69 & L.S.D 0.05 & 5.38 \\
\hline & $\begin{array}{c}P_{1} \\
M \mathbf{B}\end{array}$ & & 322.65 & & 364.40 & & \\
\hline & $\mathbf{B}_{0}$ & & 297.23 & & 331.41 & & \\
\hline & $\mathbf{B}_{1}$ & & 321.07 & & 336.48 & & \\
\hline & $\mathbf{B}_{2}$ & & 334.01 & & 370.24 & & \\
\hline \multirow[t]{2}{*}{ L.S.D } & 0.05 & & & 6.59 & & & \\
\hline & Average & & 317.44 & & 346.04 & & \\
\hline L.S.D & 0.05 & & & 3.81 & & & \\
\hline
\end{tabular}

6- Dimater of stem $(\mathrm{cm})$

Results of table 6 clearly showed that the inoculation with the mycorrhizae had significant effect. dimater stem increased from $3.68 \mathrm{~cm}$ for the non - Inoculated plants to 3.12 $\mathrm{cm}$ for the inoculated ones (M0 treatment) . Also with spray with Biozyme the dimater stem increased to 3.80 for (B1) treatment for 3.38 (B0) treatment. The Phosphalas (P1) treatment had significant effect dimater stem increased from $3.80 \mathrm{~cm}$ for the control treatment (3. $41 \mathrm{~cm})(\mathrm{P} 0)$. interaction between the inoculation with the mycorrhizae and Biozyme had significant effect. The highest of dimater stem combination treatment $(3.68 \mathrm{~cm})$ while the lowest dimater stem was recorded at the control $(3.12 \mathrm{~cm})$ (M0B0). In the same way, interaction between inoculation with mycorrhizae and the spray with the
Phosphalas had significant effect. The highest dimater stem $(3.80 \mathrm{~cm})$ was obtained at the combination treatment while the lowest dimater stem was at the control $(3.41 \mathrm{~cm})$. Spray with Biozyme along with the Phosphalas resulted in larger the dimater stem at all combination treatments. The B1P1 combination treatment was superior in its effect which resulted in the perfect dimater stem $(3.87 \mathrm{~cm})$ control treatment (B0P0) gave the lowest dimater stem $(2.87 \mathrm{~cm})$ For the combination of the three factors studied, the M1B1P0 treatment was more effective in giving the largest dimater stem $(4.03 \mathrm{~cm})$ which did not differ significantly from other combination treatments the control treatment (M0B0P0) gave the least of dimater stem (2.20 $\mathrm{cm})$.

Table 6. Effect of Mycorrhizae, spray with Biozyme and Phosphalas in dimater stem (cm) of okra cv. Ptera

\begin{tabular}{|c|c|c|c|c|c|c|c|}
\hline \multirow[t]{2}{*}{$\mathbf{P}$} & & $\mathbf{B}$ & M0 & & M1 & $\mathbf{B} \times \mathbf{P}$ & Average \\
\hline & & $\overline{B_{0}}$ & 2.20 & & 3.53 & 2.87 & 3.41 \\
\hline \multirow[t]{3}{*}{$\mathbf{P}_{0}$} & & $\mathbf{B}_{1}$ & 3.73 & & 4.03 & 3.87 & \\
\hline & & $\mathbf{B}_{2}$ & 3.97 & & 3.77 & 3.48 & \\
\hline & & Bo $_{0}$ & 3.27 & & 3.70 & 3.73 & 3.80 \\
\hline \multirow[t]{2}{*}{$\mathbf{P}_{1}$} & & $\mathbf{B}_{1}$ & 3.80 & & 3.67 & 3.87 & \\
\hline & & $\mathbf{B}_{2}$ & 3.90 & & 3.67 & 3.78 & \\
\hline \multirow[t]{6}{*}{ L.S.D } & $\begin{array}{l}0.05 \\
M \times P\end{array}$ & & & 0.44 & & 0.31 & 0.18 \\
\hline & $\mathbf{P}_{0}$ & & 3.14 & & 3.67 & L.S.D 0.05 & 0.25 \\
\hline & $\underset{M \times B}{P_{1}}$ & & 3.91 & & 3.69 & & \\
\hline & $\mathbf{B}_{0}$ & & 3.12 & & 3.63 & & \\
\hline & $\mathbf{B}_{1}$ & & 3.73 & & 3.88 & & \\
\hline & $\mathbf{B}_{2}$ & & 3.60 & & 3.68 & & \\
\hline \multicolumn{2}{|c|}{ L.S.D 0.05} & & & 0.31 & & & \\
\hline & Average & & 3.53 & & 3.68 & & \\
\hline L.S.D & 0.05 & & & 0.18 & & & \\
\hline
\end{tabular}


7- The number of nodules on the stem (nod - plant $^{\mathbf{- 1}}$ ): It was clear from table 7 show that there was a significant increase in the number of nodules on the stem due to inoculation with the mycorrhizae. Inoculation (M1) recorded higher values for the number of nods on the stem (34.39 nod . plant $\left.{ }^{-1}\right)$ than that for non-in oculated plants (30.72 nod . plant $\left.{ }^{-1}\right)$. Also treatment with ( Biozyme ) resulted in significant increase in the number of nods on the stem at $2 \mathrm{~cm} . \mathrm{L}^{-1}$ (B1) (33.33 nod. plant ${ }^{-1}$ ) compare to (31.33 nod . plant ${ }^{-}$ $\left.{ }^{1}\right)$ for the control . Treatment with the Phosphalas (P1) recorded the number of nods on the stem was (34.56 nod . plant ${ }^{-1}$ ) while in control treatment the number of legions on the stem was (30.56 nod . plant $\left.{ }^{-1}\right)$. For the interaction between the inoculation with the mycorrhizae and the spray with the (Biozyme) M1B1 combination treatment was superior in its effect plant height at this treatment was (37.17 nod . plant $\left.{ }^{-1}\right)$ while in control treatment the plant height was M0B1(29.50 nod . plant $\left.{ }^{-1}\right)$. In the same way,

Table 7. Effect of Mycorrhizae, spray with Biozyme and Phosphalas on the number of nodules on the stem (leg. plant ${ }^{-1}$ ) of okra cv. Ptera

\begin{tabular}{|c|c|c|c|c|c|c|}
\hline $\mathbf{P}$ & & $\mathbf{B}$ & $\mathbf{M}_{0}$ & M1 & $\mathbf{B} \times \mathbf{P}$ & Average \\
\hline & & $\mathbf{B}_{0}$ & 29.33 & 35.00 & 32.17 & 30.56 \\
\hline \multirow[t]{3}{*}{$\mathbf{P}_{0}$} & & $\mathbf{B}_{1}$ & 29.67 & 39.33 & 29.50 & \\
\hline & & $\mathbf{B}_{2}$ & 30.67 & 28.33 & 30.00 & \\
\hline & & $\mathbf{B}_{0}$ & 31.33 & 35.00 & 34.50 & 34.56 \\
\hline \multirow[t]{2}{*}{$\mathbf{P}_{1}$} & & $\mathbf{B}_{1}$ & 32.67 & 27.33 & 33.17 & \\
\hline & & $\mathbf{B}_{2}$ & 30.67 & 41.33 & 36.00 & \\
\hline \multicolumn{6}{|c|}{$\mathbf{M} \times \mathbf{P}$} & 0.97 \\
\hline \multicolumn{3}{|c|}{$\mathbf{P}_{0}$} & 30.89 & 30.22 & L.S.D 0.05 & 1.37 \\
\hline \multicolumn{7}{|c|}{$\begin{array}{c}\mathbf{P}_{1} \\
\mathbf{M} \times \mathbf{B}\end{array}$} \\
\hline \multicolumn{3}{|c|}{$\mathbf{B}_{0}$} & 31.33 & 31.67 & \multicolumn{2}{|c|}{31.33} \\
\hline \multicolumn{3}{|c|}{$B_{1}$} & 29.50 & 37.17 & \multicolumn{2}{|c|}{33.33} \\
\hline \multicolumn{3}{|c|}{$\mathbf{B}_{2}$} & 31.67 & 34.33 & \multicolumn{2}{|c|}{33.00} \\
\hline \multicolumn{3}{|c|}{ L.S.D 0.05} & & 1.67 & \multicolumn{2}{|c|}{1.18} \\
\hline & Average & & 30.72 & 34.39 & & \\
\hline L.S.D & 0.05 & & & 0.97 & & \\
\hline
\end{tabular}

8- The Fresh weight of vegetative $g$ ( $g$. plant $^{-1}$ ): Results of table 8 showed that the inoculation with the mycorrhizae had significant effect on the fresh weight of vegetative increased to (2906g) for the ( M1) inoculated plants compare to $(2603 \mathrm{~g})$ for the non- inoculated ones (M0 treatment). Also with spray with Biozyme the fresh weight of vegetative increased from for B2 treatment to (2858g) for (B0) treatment $(2617 \mathrm{~g})$. The Phosphalas (P1) treatment had significant effect the fresh weight of vegetative increased to $(2969 \mathrm{~g})$ for the control treatment $(2539 \mathrm{~g})$ for (P0) treatment. interaction between the inoculation with the mycorrhizae and Biozyme had significant effect. The highest fresh weight of vegetative combination treatment (3058 g) for interaction between the inoculation with the mycorrhizae and the spray with the Phosphalas, M1P1 combination treatment resulted in the number of nods on the stem with an average the number of nods on the stem (38.56 nod .plant $\left.{ }^{-1}\right)$ in compare to that for the control M0P0 (30.89 nod . plant ${ }^{-1}$ ) Also the B2P1 combination treatment, interaction between Biozyme and the Phosphalae, gave the number of nods on the stem (36.00 nod . plant $\left.{ }^{-1}\right)$, while the control treatment gave the lowest the number of nods on the stem (32.17 nod . plant $\left.{ }^{-1}\right)$. Interaction among the three factors has also significant effect . The M1B2P1 combination treatment resulted in the number of nods on the stem with an average of (41.33 nod. plant $\left.{ }^{-1}\right)$ compare to (29.33 nod. plant $\left.{ }^{-1}\right)$ for the control treatment (M0B0P0).

(M1B0) while the lowest was recorded at the control (2175 g) (M0B0). In the same way, interaction between inoculation with mycorrhizae and the spray with the Phosphalas had significant effect. The highest fresh weight of vegetative ( $3111 \mathrm{~g}$ ) was obtained at the combination treatment while the lowest was at the control (2378g). Spray with Biozyme along with the Phosphalas resulted in larger fresh weight of vegetative at all combination treatments. The (B0P1) combination treatment was superior in its effect which resulted in the prefect number of branches (3058 g) Control treatment (M0P0) gave the lowest $(2175 \mathrm{~g})$ fresh weight of vegetative). For the combination of the three factors studied, the (M1B2P1) treatment was 
more effective in giving the largest fresh weight of vegetative (3200 g) which did not differ significantly from other combination

Table 8. Effect of Mycorrhizae, spray with Biozyme and Phosphalas on the fresh weight of vegetative $\left(\mathrm{g}\right.$. plant $^{-1}$ ) of okra cv. Ptera

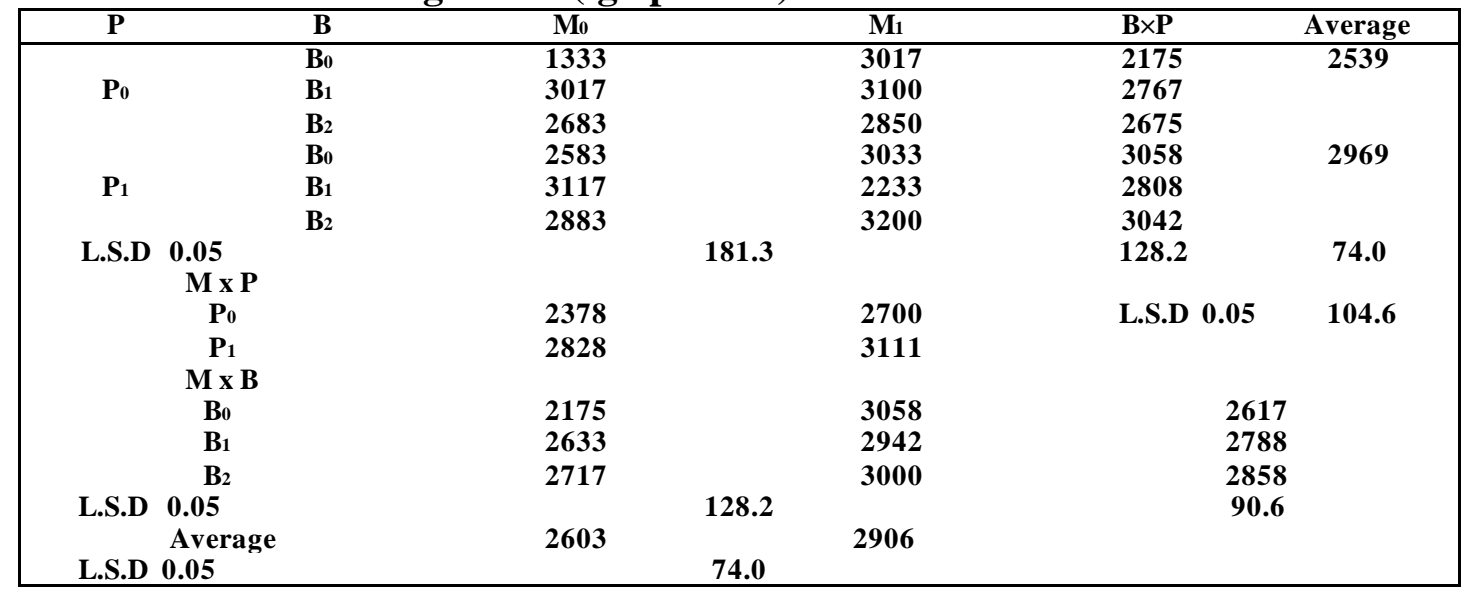

9- dry weight of the vegetative $\left(\mathrm{g} \cdot\right.$ plant $\left.^{-1}\right)$ Table 9 demonstrates the significant effect of the inoculation with the mycorrhizae in the dry weight of the vegetative .The inoculation treatment (M1) resulted in the dry weight of the vegetative $(150.3 \mathrm{~g})$ than that for the control (99.1 g) . Also, for the Biozyme treatments effects, $4 \mathrm{~cm} . \mathrm{L}^{-1}$ (B2) treatment recorded the highest dry weight of the vegetative $(150.1 \mathrm{~g})$ in compare to $(89.5 \mathrm{~g})$ for the control ( B0) Spraying the Phosphalas on plants have also promoting effect the dry weight of the vegetative. Higher dry weight of the vegetative was recorded at (P1) treatment $(136.2 \mathrm{~g})$ in compare to $(113.2 \mathrm{~g})$ for the control. It was obvious from the same table that the interaction between the mycorrhizae and spray with the Biozyme significantly increased dry weight of the vegetative. At the (M1B2) combination treatment, the dry weight of the vegetative treatments the control treatment (M0B0P0) treatment gave the least of fresh weight of vegetative( $(1333 \mathrm{~g})$.

Table 9 . Effect of Mycorrhizae, spray with Biozyme and Phosphalas in the dry weight of the vegetative (g) of okra cv. Ptera

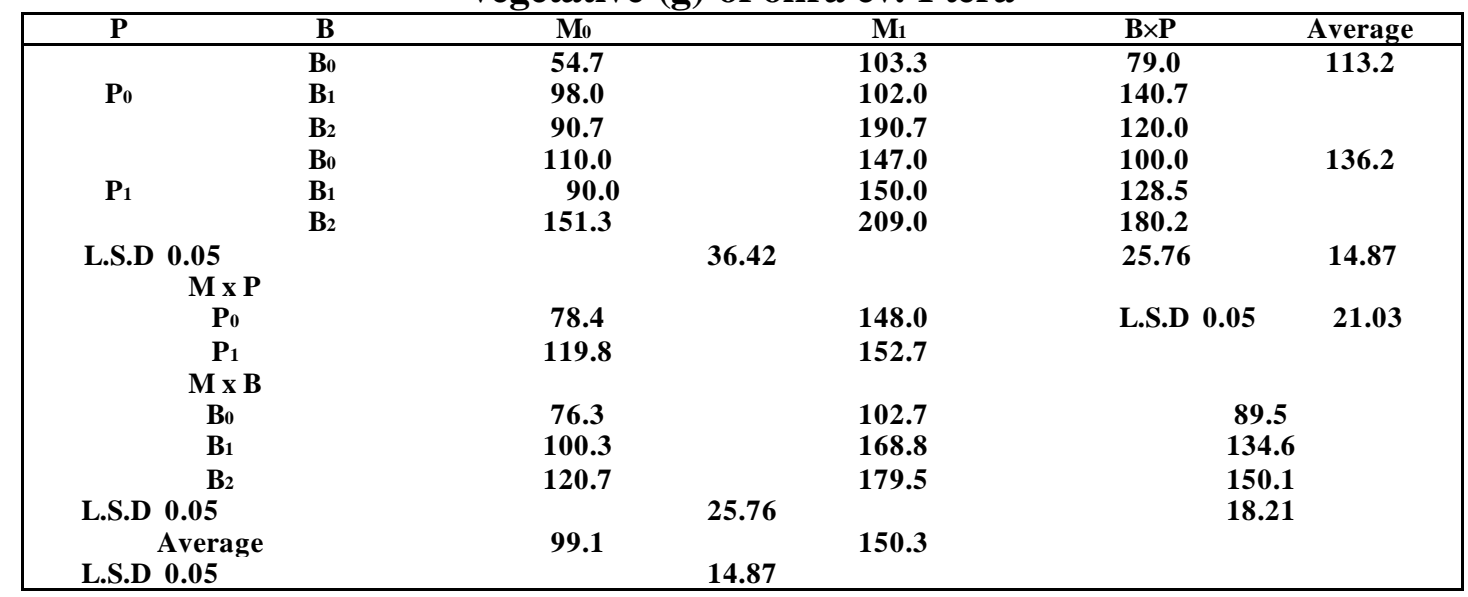


10- Total Chlorophyll estimation ( SPAD)

It was clear from table 10 that there was a significant increase in total chlorophyll due to the inoculation with the mycorrhizae. Inoculation (M1) recorded higher values for total chlorophyll (44.81 SPAD) than that for non-inoculate d plants (41.22 SPAD). Also, treatment with ( Biozyme ) resulted in significant increase in total chlorophyll especially at $4 \mathrm{~cm} \cdot \mathrm{L}^{-1}$ (B2) (44.88 SPAD) compare to (41.55 SPAD) for the control . Treatment with the Phosphalas (P1) recorded total chlorophyll of ( 44.17 SPAD) while in control treatment the total chlorophyll was (41.86 SPAD). For the interaction between the inoculation with the mycorrhizae and the spray with the (Biozyme) (M1B2) combination treatment was superior in its effect the total chlorophyll at this treatment was 49.68SPAD, which was not significantly differing from the (M0B0) combination treatment, while in control

Table 10. Effect of Mycorrhizae, spray with Biozyme and Phosphalas on total chlorophyll estimation ( SPAD) of okra cv. Ptera.

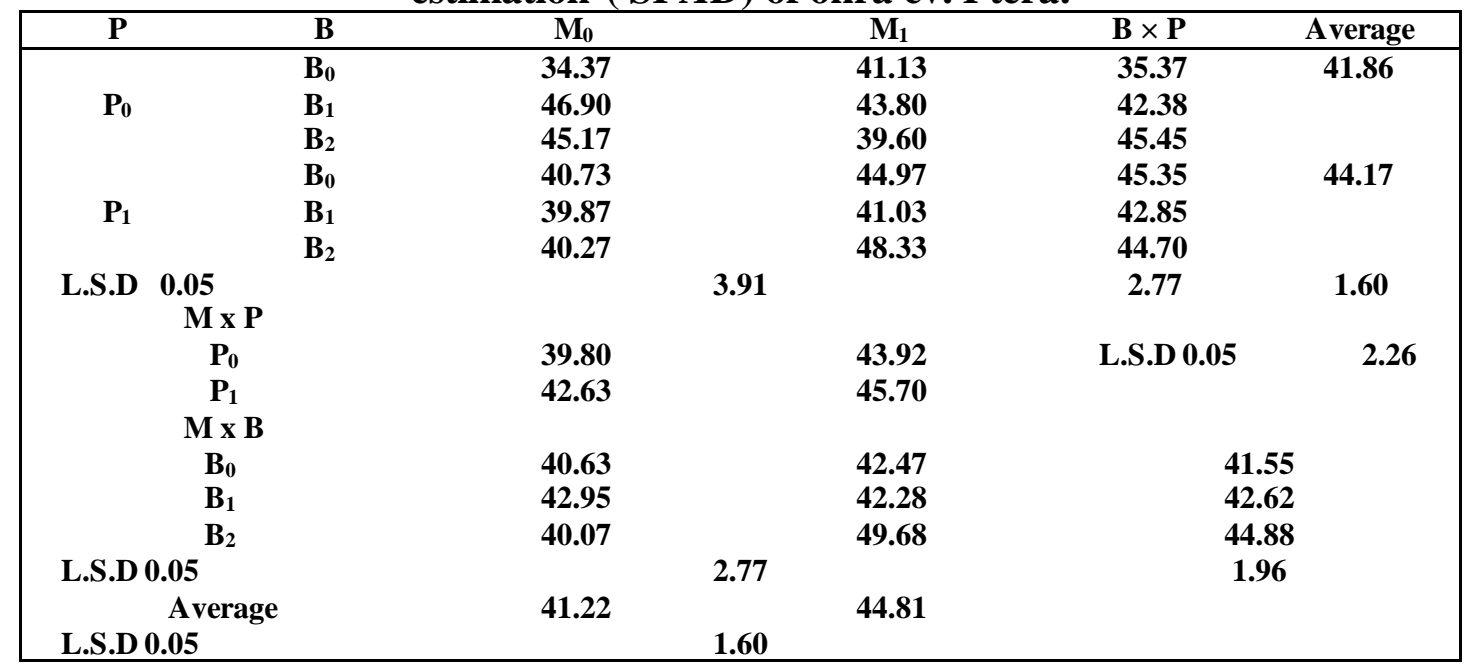

The increase in growth parameters, especially the interaction treatments between mycorrhizae inoculation and foliar application with biozyme and phosphorylase $(9,16)$ may be attributed to improving the plant growth by increasing the absorption surface aera of the the roots as the mycorrhizae hyphes reach further distonces than roots $(4,5)$. In additions the mycorrhizae Glomalin, which improves the soil aggregates and increase its abitity to retain water, and phosphors enzyme which converts organic phosphors to mineral phosphors readily absorb by plants roots (2) and (19). Siderophores produced by mycorrhizae chelate microelements such as $\mathrm{Fe}, \mathrm{Mn}, \mathrm{Zn}$, and $\mathrm{Cu}$ which affect the plants metabolism and increase its growth (6) and (12). The increase in phosphors availability by treatment the total chlorophyll was (40.07 SPAD). In the same way, for interaction between the inoculation with the mycorrhizae and the spray with the Phosphalas, (M1P1) combination treatment resulted in with an average the total chlorophyll of (45.70 SPAD) in compare to that for the control (39.80 SPAD) (M0P0). Also the ( B2P0) combination treatment, interaction between Biozyme and the Phosphalae, gave the highest the total chlorophyll (45.45 SPAD), while the control treatment gave the lowest the total chlorophyll (35.37 SPAD). Interaction among the three factors has also significant effect. The M1B2P1 combination treatment resulted in the total chlorophyll with an average 48.33SPAD) compare to( 34.37 SPAD) for the control treatment (MOB0P0). mycorrhizae increase nitrogen fixation and uptake, as well as increasing energy production required to maintain the plants metabolism, this reflects on increasing vegetative characters. Biozyme contains a group of plant growth regulators Gibbrelin, Auxin, and cytokinine) which play an important role in increasingthe permeability of cell walls, absorphon and improves root growth .Auxins and Gibbrelin increase the vegetative growth $(3,7)$. which reflects positively on increasing chlorophyll pigments (table 10). This leads to increasing the number of plant leaves, leaf surface area (table 4,5) plant height ( table 1) number of branches (table 2,3) and other parametersof vegetative characters $(1,13,18)$. 


\section{REFRENCES}

1. Abdul H, A. and Abu Al Yazeed . 2010. Effect of Paper Fertilization on the Clavicle Microbial Clays by the Amino Acids of Horticultural crops. Scientific Bulletin, Scientific Library of United Company for Agricultural Development and Ain Shams University, Egypt.PP:

2. Al-Rukabi, M. N. M., and K. D. H.AlJebory, 2017. Response of green bean to nitrogen fixing bacterial inoculation and molybdnum. The Iraqi Journal of Agricultural Science, 48(2), 413

3- AL- Obady, and R.M.Abdul Al- Hussain. 2015. Effect of foliar application with garlic extract and Liquorice root extract and Salicylic acid on vegetative growth and flowering and flower set of tomato and under unheated houses. Journal of Applied Science And Research, 3 (1) : 11- 22

4. Al-Umrany, H.H.,Abood and R.M.Abdul al-Hussain. 2019. The effect of the inoculaltion with the mycorrhizae and spray With $\mathrm{FeSO}_{4}$ and anti-transpiration on some growth characters and yield of okra Abelmoschus esculentus L.Moench 9 (1); 170 -178 .

5. Allawi, M.M. 2013. Impact of Bio, Organic and Chemical Fertilizeation on the roots Aarchitectural and Growth and Yield of Pepper Plant (Capsicum annuum). Thesis degree for Ph.D Dissertation in Horticulture and landscape Gardening. University of Baghdad, Iraq

6. Al-Jebory .K. D. H, and M. N. M. AlRukab.2017. Effet of bio-fertilzers and molybdenum on growth and yield of green bean. The Iraqi Journal of Agricultural Sciences -681-689: (3) 48.

7. Al-Khafaji M . A.2014. Plant Growth Regulators , Applicution and utilization in Horticulture . Minsitry of Higher Eduction and Scientific Research University of Baghdad. Collage of Agriculture PP :348

8. Alwan, U. A., and H. M. Aboud.2017. "Impact of bio-fertilizers, salcylic acid on occurance of soil beneficial organisms and Concentration of some Chamical Compounds in common beans phaseolus irrigated with saline water."Iraq Journal of Agriculture. 22. No. (6).
9. Al-Samerria, I. K. and H. S. Rahi. 2006. The effect of inoculation with Azotobacter and Azospirillum on some mineral acguisition, phytohormon and growth of tomato seedlings. Iraqi Journal of Agricultural Sciences. 37 (3): 27-32..

10. Al- Samrria, I.KH and F.M.Al-Tamimi. 2018.Concepts and Applied of soil Micorobiology .Minstry of Higher Education and Scientific.Diyala University. PP: 516

11. Ali, N.Sh. and Abd.A.Shakir .2018. Organic fertilizertion and its role in Sustainable Agriculture .Dar Al-Kutoob . Baghdad pp. 216

12. Ahmed, E.and S. j. Holmstrom . 2014. Siderophores in environmental research : role and application microbial biotechnology . WWW// ncbi.inm.nih .gov

13. Beake,R ; P.P. Mohapatra., T . Aslam., D.Manna; A.Sarkar and T.K.Maity . 2017.Efficacy of biozyme on yield and attributthng trais in potato ( Solanum tuberosum L .) . Journal article .Environmental 35 (2), 1575 - 1579

14. Douds ,D,D;G.Nagahashi ; C.Reider and P, Hepperrly .2007.Inoculation with am fungi increaaes the yield of potatoes in high $\mathrm{p}$ soil . Biological - Agricutlure and Horticutlure $.25 ; 67-78$

15. Hadeer, A.S.R, S. Radhi .2017. Effect of Local Biofertilizer Produced from Bacillus megaterium, Bacillus subtilis AND Bacillus mucilaginosus and Imported Biofertilizer on Growth and Yield of Potato Solanum tuberosum L. Iraqi Jornal of Desert Studies. Volume: 8 Issue: 2 Pages: 53-65

16. Lu ,Li-H and Q-Sh.Wu . 2017 . Mycorrhizae promote plant growth, root morphology and chlorophyll production in white clover .Biotechnology . 16 . Iss :1 P: 3439

17. Mohammedi, Sh.; F.; Musleh . and M .AlMohammadi. 2012 .Planning and Design Experiments. Dar Osama Publishing \& Distribution. Oman . Jourdan

18. Sabry .R. E, and S. A. Abdal-Latife.2017. Effect of fertilizers on growth of some turfgrass plant. The Iraqi Journal of Agricultural Sciences -1624-1633: (2) 48 .

19- Simth , E.S; I .Jokobson ., M.Gron;und and F.A.Smith . 2011. Roles of arbuscular mycorrhizae in plant Phosphorus nutrition : 
interactions between pathways of Phosphorus uptake in atbuscular mycorrhizae roots have important impliacations . plant Physiology 156 (3), 1050- 1057

20. Uillines ,Zawn . 2019 . Is okra good for diabetes ( antide) WWW .medicalnewsts today .com
21-Vispute ,S. and A.Khopade .2011. Glycyrrhiza glabra Linn- Klitaka .Areview .Int.j.Pharma Bio.Sci.2(3); 42-51.

22. $\mathrm{Wu}$, Q.S.,A.K. Stivastava and Y.Mzou .2013.Amf-induced tolerance to drought stress in citrus : Areview.- Scientific . Horticulture 164: $77-87$ 